\title{
Induction of Lymphokine-Activated Killer (LAK) Cells Against Human Leukemia Cells*
}

J. V. Teichmann, W.-D. Ludwig, H. Seibt-Jung, G. Sieber, and E. Thiel

\section{A. Introduction}

Lymphokine-activated killer (LAK) cells are known to lyse fresh solid tumor cells in vitro [1], and clinical studies suggest that adoptive immunotherapy with LAK cells and interleukin-2 (IL-2) may be a promising approach in the treatment of solid tumors $[2,3]$. As only few data are available on the LAK cell system in connection with human leukemia $[4,5]$, we investigated the induction of LAK cells against human leukemia cells in vitro and studied the augmentation of cytotoxic mechanisms which may be achieved by the combined application of different lymphokines or the coculturing of effector cells with tumor cells.

\section{B. Materials and Methods}

\section{Lymphokines}

Recombinant IL-2 and rIFN- $\gamma$ were generous gifts from the Glaxo Institute of Molecular Biology, Geneva, and the Ernst-Boehringer Institute, Vienna.

\section{Induction of LAK Cells}

Allogeneic human LAK cells were generated from peripheral blood mononuclear cells obtained from healthy volunteers and cultured $\left(1 \times 10^{6} / \mathrm{ml}\right)$ for 6 days with rIL-2 $(1000 \mathrm{U} / \mathrm{ml})$. In some experiments, we induced LAK activity from bone mar-

Dept. of Hematology and Oncology, Klinikum Steglitz, Free University of Berlin, D-1000 Berlin, FRG

* Supported by the Deutsche Krebshilfe e.V., Bonn (W 19/87/Te 1) row $(\mathrm{BM})$ or peripheral blood $(\mathrm{PB})$ of leukemia patients by long-term culturing (14-24 days) of mononuclear cells in the presence of IL-2.

\section{Target Cells}

Fresh leukemic cells were obtained from BM or PB of untreated patients by Ficoll-Hypaque gradient centrifugation. Phenotypic analyses were performed by standard indirect immunofluorescence asssays as described elsewhere [6]. K 562 and Daudi cells, maintained in continuous cultures, served as standard target cells. For use in the cytotoxicity assay, fresh leukemic cells and cell lines were labeled with $300 \mu \mathrm{Ci}$ or $50 \mu \mathrm{Ci}$ sodium chromate respectively.

\section{Cytotoxicity Assay}

Lymphokine-activated killer cell activity was determined in a standard $4-\mathrm{h}{ }^{51} \mathrm{Cr}$ release assay using $5 \times 10^{3}$ target cells and various effector-to-target $(\mathrm{E}: \mathrm{T}) \mathrm{ra}$ tios.

\section{Results and Discussion}

Leukemic cells from 62 patients were evaluated for their susceptibility to the lytic effect of allogeneic LAK cells. A significant lysis (defined as over $20 \%$ specific lysis at an $E: T$ ratio of $100: 1$ ) was found in about two-thirds of the leukemias examined (Table 1). No substantial differences could be detected between myeloid and lymphoid leukemias or with regard to the immunological phenotype. 


\begin{tabular}{|c|c|c|c|}
\hline \multirow[t]{2}{*}{ Target cells } & \multirow[t]{2}{*}{$n$} & \multicolumn{2}{|c|}{$\begin{array}{l}\text { Cytotoxicity (\% specific } \\
\text { lysis) E:T } 100: 1\end{array}$} \\
\hline & & $>20 \%$ & $<20 \%$ \\
\hline AML & 22 & 15 & 7 \\
\hline CML-BC & 4 & 3 & 1 \\
\hline CML chronic phase & 3 & 2 & 1 \\
\hline ALL & 29 & 17 & 12 \\
\hline O-ALL & 4 & 2 & 2 \\
\hline c-ALL & 15 & 13 & 2 \\
\hline B-ALL & 2 & 1 & 1 \\
\hline T-ALL & 8 & 1 & 7 \\
\hline B-CLL & 4 & 2 & 2 \\
\hline Total & 62 & 39 & 23 \\
\hline
\end{tabular}

Table 1. Susceptibility of fresh leukemic cells to allogeneic LAK cells

AML, acute myeloblastic leukemia; CML, chronic myelocytic leukemia; ALL, acute lymphoblastic leukemia; CLL, chronic lymphocytic leukemia.

There is growing evidence that leukemia patients have impaired natural killer (NK) cell functions, and this may contribute to leukemogenesis $[5,7]$. We therefore studied the possibility of using IL-2 to activate NK cells of leukemic patients. In the presence of IL-2, long-term culturing of mononuclear cells from

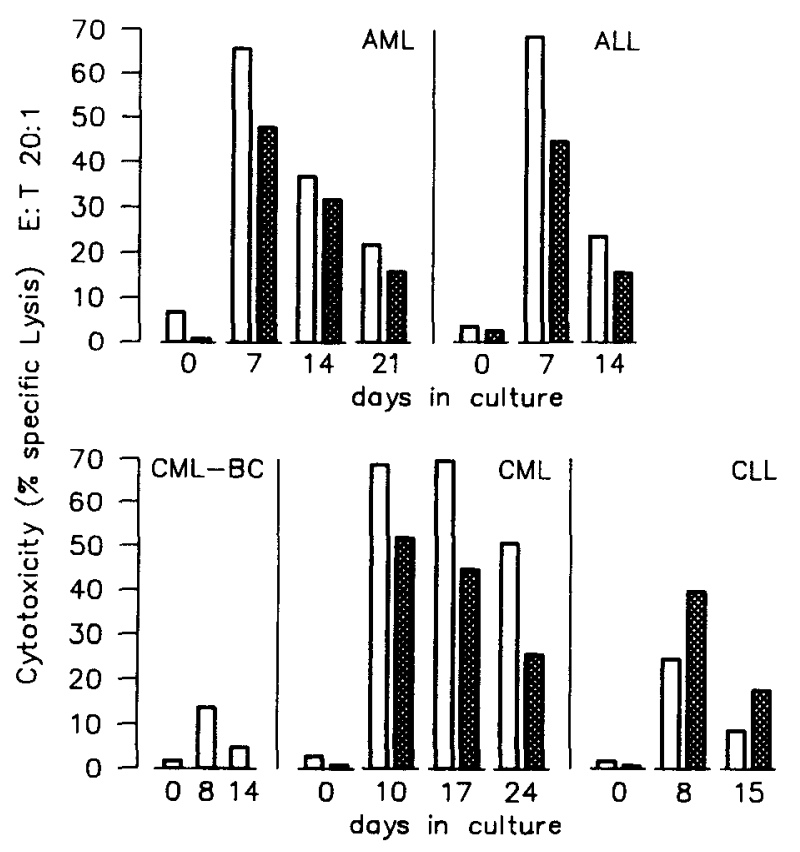

Fig. 1. Induction of LAK cells from BM or $\mathrm{PB}$ of leukemia patients by long-term culturing of mononuclear cells in the presence of IL-2 $(1000 \mathrm{U} / \mathrm{ml})$ against K $562(\square)$ and Daudi (장) target cells leukemia patients' $\mathrm{BM}$ or $\mathrm{PB}$, containing a high percentage of tumor cells, resulted in induction of highly active cytotoxic cells. During culturing, the number of malignant cells decreased, while residual large granular lymphocytes (LGLs) expanded and developed lytic activity against NK-sensitive (K 562) and NKresistant (Daudi) target cells (Fig. 1). These cultures of leukemic cells and residual normal mononuclear cells resemble tumor-infiltrating lymphocytes (TILs), which are known to be more active than LAK cells generated from peripheral blood [8]. As demonstrated, the application of IL-2 in vitro can result in an activation and expansion of LGL even in highly leukemic patients, suggesting that the generation of LAK cells by IL-2 in vivo, e.g., after chemotherapy, may be therapeutically useful in preventing the relapse or spread of leukemia.

Reports that endogenous IFN- $\gamma$ is required for IL-2 induction of LAK cells [9] led us to conjecture that it might be possible to augment LAK activity by addition of rIFN- $\gamma$ during the activation process. The results of our studies show that the combined application of rIFN- $\gamma$ and rIL-2 can improve the effectivity of cytotoxic mechanisms even at a low $\mathrm{E}: \mathrm{T}$ ratio of 2.5:1 (Fig. 2). The sequential ad- 
Fig. 2. Improvement of the effectivity of cytotoxic mechanisms: combined sequential application of rIL-2 and rIFN- $\gamma$

\begin{tabular}{ll}
$\begin{array}{ll}\text { Induction of LAK cells } \\
\mathrm{IL}-2\end{array}$ & $\begin{array}{l}\text { IFN-gomma } \\
(\mathrm{U} / \mathrm{ml})\end{array}$ \\
\hline & $(1000 \mathrm{U} / \mathrm{ml})$ \\
1000 & - \\
1000 & $+($ simultaneous with $\mathrm{L}-2)$ \\
1000 & $+(24 \mathrm{~h}$ before $\mathrm{LL}-2)$ \\
500 & - \\
500 & $+($ simultaneous with $\mathrm{LL}-2)$ \\
500 & $+(24 \mathrm{~h}$ before $\mathrm{LL}-2)$ \\
100 & - \\
100 & $+($ simultoneous with $\mathrm{LL}-2)$ \\
100 & $+(24 h$ before $\mathrm{LL}-2)$
\end{tabular}

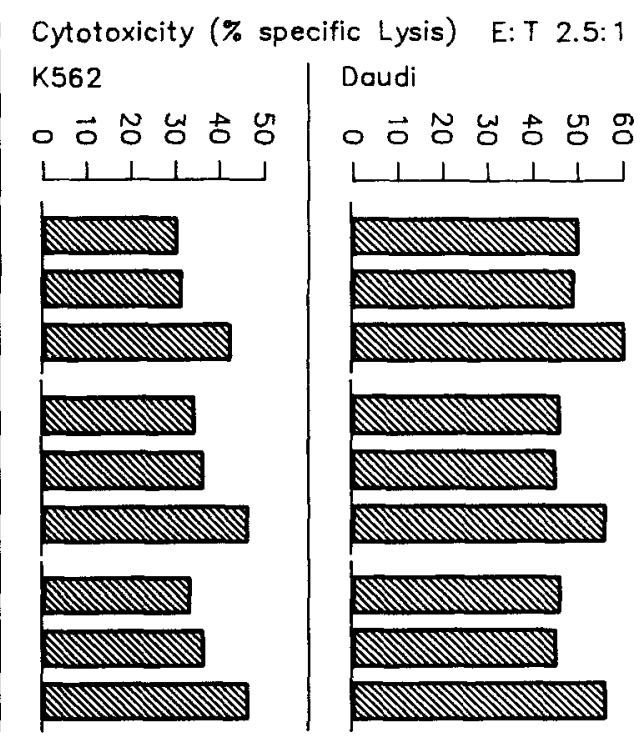

$$
\begin{aligned}
& \text { induction of LAK cells } \\
& (\mathrm{U} / \mathrm{ml}) \quad(1000 \mathrm{U} / \mathrm{ml}) \\
& \begin{array}{ll}
1000 & - \\
1000 & +(\text { simultoneous with } \mathrm{LL}-2) \\
1000 & +(24 \mathrm{~h} \text { before } \mathrm{LL}-2) \\
500 & - \\
500 & +(\text { simultaneous with } \mathrm{L}-2) \\
500 & +(24 \mathrm{~h} \text { before } \mathrm{L}-2) \\
100 & - \\
100 & +(\text { simultoneous with } \mathrm{LL}-2) \\
100 & +(24 h \text { before } \mathrm{LL}-2)
\end{array}
\end{aligned}
$$

\begin{tabular}{|c|c|c|c|c|}
\hline \multicolumn{2}{|c|}{ Induction of LAK cells } & \multicolumn{3}{|c|}{$\begin{array}{l}\text { Cytotoxicity (\% specific lysis) } \\
\text { E:T } 20: 1\end{array}$} \\
\hline $\begin{array}{l}\text { IL-2 } \\
(1000 \mathrm{U} / \mathrm{ml})\end{array}$ & $\begin{array}{l}\text { Leukemia cells } \\
\text { (mitomycin-Tx) }\end{array}$ & K 562 & Daudi & AML \\
\hline- & - & 6 & 5 & 0 \\
\hline+ & - & 50 & 42 & 10 \\
\hline- & K 562 & 1 & 0 & 0 \\
\hline+ & K 562 & 69 & 53 & 17 \\
\hline- & Daudi & 49 & 25 & 3 \\
\hline+ & Daudi & 64 & 79 & 22 \\
\hline- & AML & 7 & 6 & 1 \\
\hline+ & AML & 79 & 33 & 19 \\
\hline
\end{tabular}

Table 2. Improvement of the effectivity of cytotoxic mechanisms: coculturing of effector cells (R) with IL-2 and mitomycintreated tumor cells (S) at an $\mathrm{R}: \mathrm{S}$ ratio of $5: 1$

AML, acute myeloblastic leukemia.

ministration of rIFN- $\gamma 24 \mathrm{~h}$ before IL-2 resulted in a higher augmentation of cytotoxicity than the simultaneous application of both lymphokines. This may be due to induction of IL-2 receptors on the effector cells before they are affected by IL-2, resulting in a more efficient activation or a recruitment of additional cell populations which are not activated by IL-2 alone. Generation of more active LAK cells for clinical application should improve their therapeutic efficacy. This could reduce the necessary dosage and/or treatment time of IL-2 and thus also its toxicity.

The target structures of tumor cells which are recognized by NK cells or
LAK cells have not yet been defined. As there are data indicating that in vitro culturing of human peripheral blood mononuclear cells (PBMCs) with Blymphoblastoid cell lines results in a preferential proliferation of NK cells [10] and that NK cells can be activated by direct stimulation with the NK-sensitive tumor cell line K 562 [11], we hypothesized that LAK cell activity could possibly be augmented by coculturing effector cells with tumor cells in the presence of IL-2. Our studies with mitomycin-treated K 562 or Daudi cell lines as well as fresh leukemia cells in culture with effector cells and IL2 showed marked augmentation of cytotoxicity compared with cultures of 
PBMCs with IL-2 alone (Table 2). This may be due to target cell structures being present during the activation process and giving additional signals for the generation of LAK cells.

The results of these studies suggest that IL-2-induced lymphokine-activated killer (LAK) cells may be of great value in the treatment of leukemia, especially when the tumor burden is low, e.g., during maintenance chemotherapy to eliminate minimal residual disease or in early relapse. The combined application of different lymphokines or the coculturing of effector cells with IL-2 and tumor cells are possible approaches for improving the effectivity of cytotoxic mechanisms.

\section{References}

1. Grimm EA, Mazumder A, Zhang HZ, Rosenberg SA (1982) Lymphokine-activated killer cell phenomenon. Lysis of natural killer-resistant fresh solid tumor cells by interleukin 2-activated autologous human peripheral blood lymphocytes. J Exp Med 155:1823-1841

2. Rosenberg SA, Lotze MT, Muul LM, Chang AE, Avis FP, Leitman S, Linehan WM, Robertson CN, Lee RE, Rubin JT, Seipp CA, Simpson CG, White DE (1987) A progress report on the treatment of 157 patients with advanced cancer using lymphokine-activated killer cells and interleukin-2 or high-dose interleukin-2 alone. N Engl J Med 316:889-897

3. West WH, Tauer KW, Yannelli JR, Marshall GD, Orr DW, Thurman GB, Oldham RK (1987) Constant-infusion recombinant interleukin-2 in adoptive immunotherapy of advanced cancer. N Engl J Med 316:898-905
4. Oshimi K, Oshimi Y, Akutsu M, Takei Y, Saito H, Okada M, Mizoguchi H (1986) Cytotoxicity of interleukin 2-activated lymphocytes for leukemia and lymphoma cells. Blood 68:938-948

5. Lotzová E, Savary CA, Herberman RB (1987) Induction of NK cell activity against fresh human leukemia in culture with interleukin 2. J Immunol 138:27182727

6. Ludwig W-D, Bartram CR, Ritter J, Raghavachar A, Hiddemann W, Heil G, Harbott J, Seibt-Jung H, Teichmann JV, Riehm H (1988) Abiguous phenotypes and genotypes in 16 children with acute leukemia as characterized by multiparameter analysis. Blood 71:1518-1528

7. Lotzová E, Savary CA, Herberman RB, Dicke KA (1986) Can NK cells play a role in therapy of leukemia? Nat Immun Cell Growth Regul 5:61-63

8. Belldegrun A, Muul LM, Rosenberg SA (1988) Interleukin-2 expanded tumor-infiltrating lymphocytes in human renal cell cancer: isolation, characterization, and antitumor activity. Cancer Res 48:206214

9. Itoh K, Shiiba K, Shimizu Y, Suzuki R, Kumagai K (1985) Generation of activated killer (AK) cells by recombinant interleukin-2 (rIL-2) in collaboration with interferon-gamma (IFN- $\gamma$ ). J Immunol 134:3124-3129

10. Perussia B, Ramoni C, Anegon I, Cuturi MC, Faust J, Trinchieri G (1987) Preferential proliferation of natural killer cells among peripheral blood mononuclear cells cocultured with B-lymphoblastoid cell lines. Nat Immun Cell Growth Regul 6:171-188

11. Phillips JH, Lanier LL (1985) A model for the differentiation of human natural killer cells. Studies on the in vitro activation of Leu- $11^{+}$granular lymphocytes with a natural killer-sensitive tumor cell, K 562. J Exp Med 161:1464-1482 